\title{
Risk Assessment Procedure in Industrial Zones
}

\author{
Aleš Bernatík ${ }^{1 *}$, Pavel Šenovský ${ }^{2}$ \\ 12. VŠB-Technical University of Ostrava, Faculty of Safety Engineering, Lumírova 13, 70030 Ostrava-Výškovice; Czech Republic
}

\section{BIOGRAPHICAL NOTES}

Aleš Bernatík, assoc. prof., Ing., PhD., 2. 10. 1972, graduated 1995 at VSB-Technical University of Ostrava in area of Environmental Protection, doctor in Methodology for Industrial Risk Assessment, in 2007 was habilitated. Position: the vice-dean for science and research of Faculty of Safety Engineering (2002-20012), now deputy of head of Department of Safety Management. Great experience in risk analysis of industrial accidents, author of publications in the area of major-accident prevention.

\section{KEY WORDS}

Industrial zone, serious accident, risk, prevention.

\section{ABSTRACT}

The objective of this article is to introduce the proposal of the methodical procedure of the assessment of risks of technological equipment accidents situated especially in industrial zone sites. Synergetic phenomena or domino effects can occur in this type of dangerous equipment. The article aims especially on the risks emerging from the presence of dangerous substances, usually in smaller quantities and thus not subject to the legislation for the prevention of serious accidents.

\section{Introduction}

The term industrial zone is generally explained [1] as a self-contained complex of compact universal objects suitable for light, hygienically harmless production with effectively solved transportation and high proportion of greenery among the objects.

The operation in these zones is completely situated inside the objects, which normally miss the fenced off yards, with a free movement of visitors. Thus the industrial zone is a selfcontained complex of industries and services with many integrated functions of special character. This complex utilizes, to a great extent, mutual support of individual companies in information exchange, consultancy, joint presentation, and exploitation of international contacts. The aim of this synergy is to achieve better results and is utilized regularly in this field. [1]

The synergetic effects of accidents or other emergencies come into focus gradually2]. That is mainly because of the fact that industrial objects are considered separately from the point of view of fire safety, not in the link-up to surrounding objects belonging to other entrepreneurs.

The risk assessment and analysis in industrial zones helps to identify the sources of risks and to determine the measures for their elimination or reduction. The article deals with the companies, whose risks are connected to dangerous chemical substances. The Council Directive 96/82/EC on the control of major-accident hazards involving dangerous substances (so called SEVESO II Directive) is in force for these companies. This directive defines the limiting amounts of substances, whose overrun places the enterprise under the force of this legislation. Such an enterprise must then fulfill certain conditions. However, some enterprises exist 
that have smaller amounts of dangerous substances but can still be dangerous [3]. This article deals with these enterprises.

The basic aim of this study is to propose the methodical procedure of the assessment of risks of those sources that do not come under the force of the Act on the prevention of major accidents, and thus enable the effective risk assessment of major accidents at technological facilities that are so far practically omitted. The proposed procedure is basically intended for industrial zones but can be used at other non-classified enterprises.

\section{Risk Assessment Procedure in Industrial Zones}

In connection with the development of industrial zones, the possible dangers, caused by broadening infrastructure in zones and the operation of industrial parks, must be considered. Since this problem represents completely new field of the complex safety assessment of an area, it would be appropriate to define the aims that can be achieved by the risk analysis of industrial zones at the first place, see for example the project results [4]:

- introduction of risk assessment method for industrial zones,

- transfer of gained information and knowledge to public administration,

- utilization of the method in the frameworks of population protection measures, crisis management and preparedness of IRS to possible cases of synergetic emergencies.

The method is aimed on the assessment and control of risks at such facilities whose danger to population, property and environment emerge from the presence of dangerous chemical substances and their potential synergetic effects but at the same time the amount of those substances is so low that it does not fulfill the conditions of the Act on the prevention of major accidents. The presence of flammable, explosive, toxic and other dangerous substances is a characteristic feature of these non-classified enterprises. The proposed method is intended especially for the assessment and control of risks of typical facilities that are not classified under the SEVESO II Directive due to smaller amount of dangerous substances (DS), for example risk sources with the amount of ammonia up to 50 tons, chlorine up to 10 tons or LPG to 50 tons.

A flow chart of recommended procedure of preliminary risk assessment of industrial zones is shown in Figure 1, by means of a functional diagram of UML language. The under-mentioned algorithm has been transformed into the form of questions that have been completed in a control list. This control list has been divided into three parts according to color differentiation on Figure 1, namely inner causes, outer endangerment, and management. Further process of risk assessment will be introduced in the following text.

The method of detailed assessment of synergy risks of non-classified risk sources recommends a suitable approach by means of two levels, where the depth and demands of assessment increase gradually.

\section{Selection of facility for detailed risk assessment; 2. Detailed assessment of synergy effects.}

The recommended procedure of the assessment of risks of non-classified risk sources is schematically shown in the following algorithm (Figure 2).

Table 1: Defined threshold amount of dangerous substances [5]

\begin{tabular}{|l|l|l|l|}
\hline Properties of Substances & \multicolumn{3}{l|}{ Defined threshold amount Ma [kg] } \\
\hline & Solids & Liquids & Gases \\
\hline 1. Highly toxic & 10000 & 1000 & 100 \\
\hline 2. Toxic & 100000 & 10000 & 1000 \\
\hline 3. Oxidizing & 10000 & 10000 & 10000 \\
\hline 4. Explosive (defined by law in note 2) & 10000 & 10000 & - \\
\hline 5. Explosive (defined by law in note 2) & 1000 & 1000 & - \\
\hline 6. Flammable & - & 10000 & - \\
\hline 7. Highly Flammable & - & 10000 & - \\
\hline 8. Extremely Flammable & - & 10000 & 1000 \\
\hline 9. Dangerous to Environment & 100000 & 10000 & 1000 \\
\hline 10. Classified by R phrases R14, R14/15, R291 & 10000 & 10000 & - \\
\hline
\end{tabular}

According to the EU Regulation 1272/2008 on classification, labeling and packaging of substances and mixtures corresponds to the classification by standard hazard statement H260 and supplementary hazard statement EUH 029 


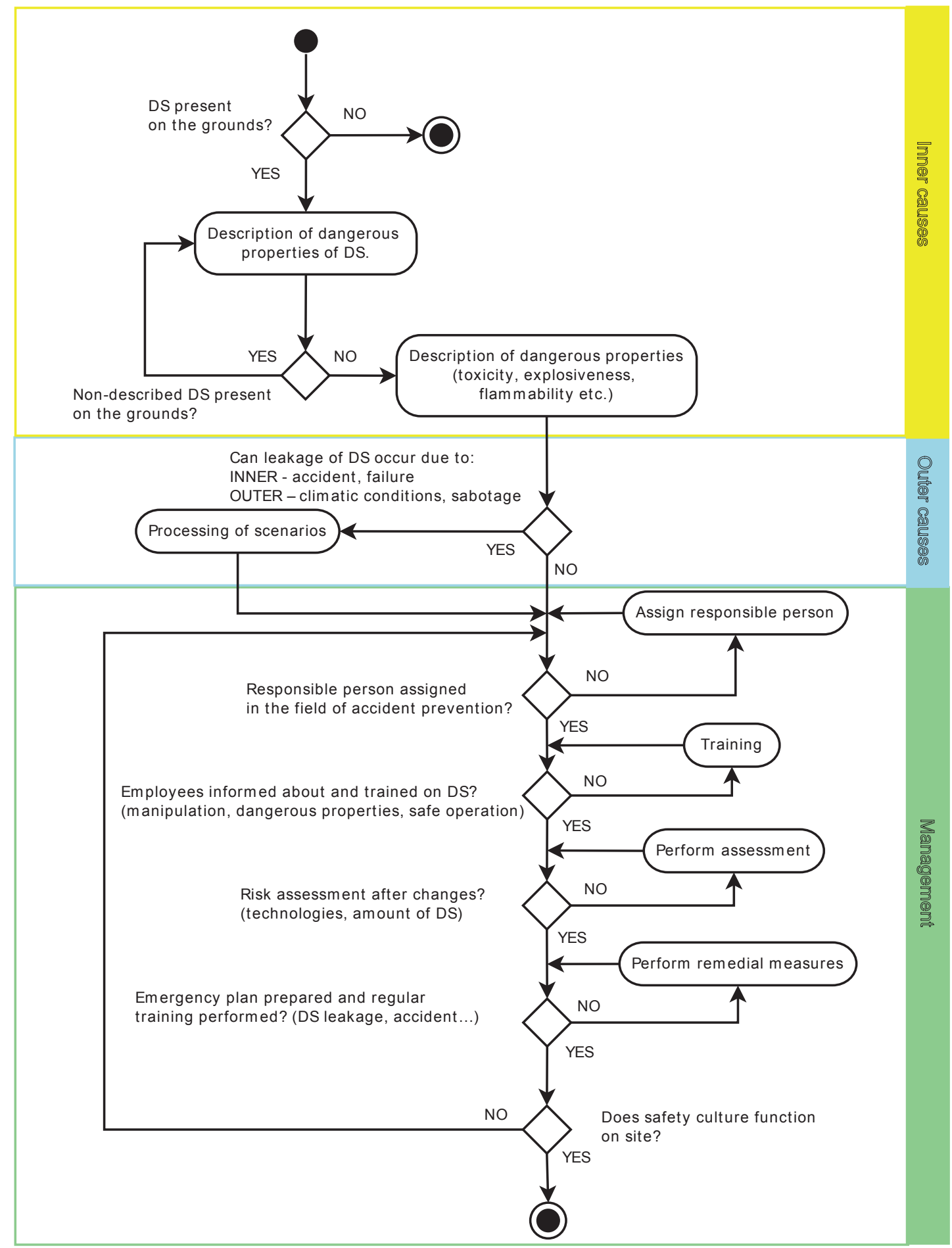

Fig. 1: Flow chart of preliminary assessment of smaller sources 


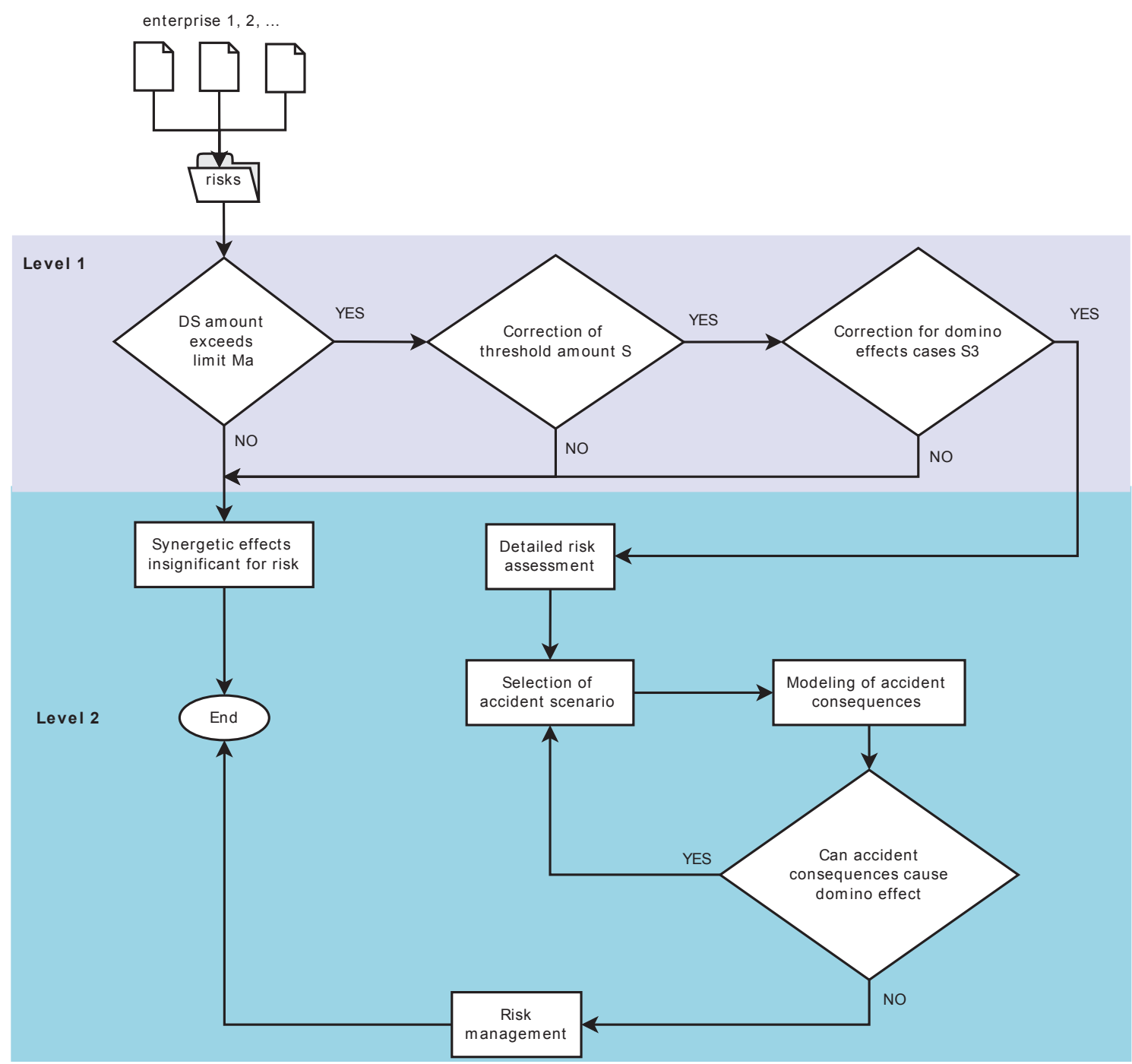

Fig. 2: Flow chart of synergy effects assessment in industrial zones

\subsection{Selection of major risk sources}

The process risk sources selection was adopted from the ARAMIS method [5] as the output of 5th EU framework program project. Specifically, the procedure is based on the VADE MECUM method from z Belgium [6]. The selection of risk sources is a critical step in any risk analysis. If too many facilities are selected, the analysis will be unnecessarily time demanding. On the other hand, in case of small number of selected facilities, the risks could be underestimated [7], which is undesirable as well.

The facilities containing dangerous substances are selected for further assessment if the amount of dan- gerous substances is higher than defined threshold amount Ma (see Table 1).

This threshold amount is specified in dependence on dangerous properties of substances, their physical state and placement in relation to other dangerous equipment. Equipment like pipelines, having lower content of dangerous substances than threshold amount but during ten minutes can leak higher amount than given limit, are also selected as significant sources of risk.

This method of risk sources selection cannot be used blindly. If some facility is assessed as dangerous in relation to the presence of dangerous sub- 


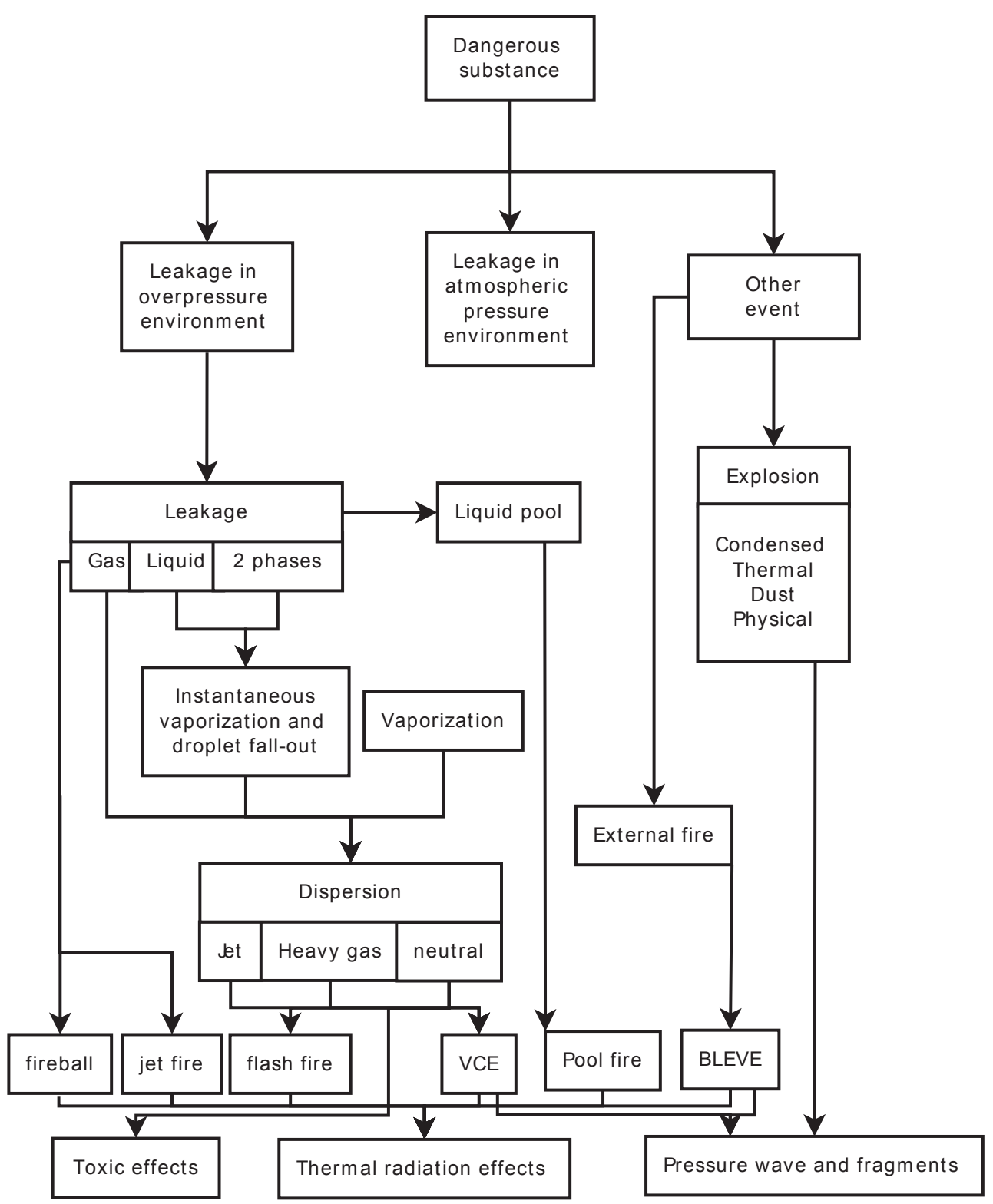

Fig. 3: Diagram of physical effects and possible accident expansion. [8]

Table 2: Threshold values for synergetic effects modeling.

\begin{tabular}{|l|l|}
\hline Type of effect & Threshold Value \\
\hline Pool fire & $\begin{array}{l}5-10 \mathrm{~kW} / \mathrm{m}^{-2} \text { deadly zone for open space, } \\
35 \mathrm{~kW} / \mathrm{m}^{-2} \text { deadly zone inside buildings }\end{array}$ \\
\hline Jet fire & $\begin{array}{l}5-10 \mathrm{~kW} / \mathrm{m}^{-2} \text { deadly zone for open space, } \\
35 \mathrm{~kW} / \mathrm{m}^{-2} \text { deadly zone inside buildings }\end{array}$ \\
\hline BLEVE - Boiling Liquid Expanding Vapor Explosion & $\begin{array}{l}5-10 \mathrm{~kW} / \mathrm{m}^{-2} \text { deadly zone for open space, } \\
35 \mathrm{~kW} / \mathrm{m}^{-2} \text { deadly zone inside buildings }\end{array}$ \\
\hline VCE - Vapor Cloud Explosion & $140-250 \mathrm{mBar}$ \\
\hline
\end{tabular}


stance or operational conditions inside the facility, it can be selected as significant, even though the amount of substance in facility is lower than the threshold one. Other equipment can be also selected, in accordance with practical experience with past accidents.

\subsection{Detailed assessment of synergetic effects}

In case of accidents in industrial zones caused by dangerous substances, a lot of accident manifestations can occur. Basic forms of accident manifestations are summarized in the following diagram according to the methodical instruction of the Czech Ministry of Environment [8].

Three main categories of accident effects exist: toxic gases effects, thermal radiation effects, and pressure wave effects with possible flying debris. These effects can impact human lives, property damage, and environmental damage. From the synergetic effects (so called. domino effects) point of view, especially the effects of fires, explosions and flying debris are significant $[9,10]$. Due to the complexity of flying debris range calculations, the following types of fires and explosions are taken into account from the synergetic effects assessment point of view, and the following threshold values can be given for the purpose of the modeling of individual (see Table 2).

\section{List of Measures for Risk Reduction}

Further, the recommended precautions and measures for risk reduction are given, where the field of risk management follows up with risk assessment. Basic division of safety precautions for risk reduction:

- Technical measures - such measures in equipment construction that lead to the increase of plant safety (examples: safety valves, sprinklers, automatic regulation, safety reservoirs, double-skin storage tanks...)

- Organizational measures - measures in work organization, regulations, technological procedures (including pertinent technical equipment) leading to the increase of plant safety.

Synergetic effects and domino effects can be also prevented using barriers limiting the possibility of initiation of consequent accidents and emergencies initiated by "covered" risks. Such barriers can be:

1. Passive barriers: functioning permanently with- out human intervention, energy sources, and without sources of information. Passive barriers can be physical (safety reservoirs, walls...), permanent barriers (corrosion prevention system) or internally safe design of equipment/facility.

2. Active barriers: must be activated to function. Active barriers always require the sequence: detection - diagnostics - action.

3. Requiring human intervention: broadly interpreted, includes monitoring of all senses, communication, thinking, physical activities, emergency activities. Human intervention can be part of the sequence: detection - diagnostics - action.

Complete summary of safety measures from the point of view of synergetic effects risks minimization is given in the following list of barriers ranked into individual groups:

Safe process management

- Spare energy sources

- Cooling

- Emergency standstill

- Computer driven process

- Operational instructions/procedures

- Summary of reactive compounds

- Performes risk assessment

- Assembly of safety valve

- Safety valve against underpressure (vacuum)

- Regular maintenance and cleaning of equipment

- Protective work aids (for employees)

Separability of materials

- Remotely controlled armatures

- Reflux valves for the prevention of reverse flow

- Safety valves in pipelines

- Discharges / purge

- Drainage

- Blocking / Interlock

- Safe distances between equipment

Elements of explosion protection

- Control of potential explosion

- Explosion-proof instruments

- Flame fuses

- Usage of inert gas

Elements of fire protection

- Detection of gas leakage

- Construction steel / fire resistant finishing

- Fire water supply

- Special systems (CO2, halons, smoke detectors, etc.)

- Water drench systems / sprinklers 
- Automatic water curtains

- Foam spray

- Handheld fire extinguishers / fire annunciators

- Cable protection

Measures against dangerous liquids leakage

-Measurement of surface level in storage tank / equipment

- Double-skin storage tanks

- Place storage tanks with liquids into safety reservoirs or tanks

- Fitting the safety reservoirs by pump connected to plant sewage

- Sewage water control before leaving the plant

Measures against gaseous substances leakage

- Toxic gas detectors

- Devices detecting the oxygen concentration

- Fitting water drench systems to equipment (hand operated or automatic sprinklers)

Measures against external influences

- Flood and inundation protection

- Protection against natural external effects

- Monitoring cameras

- Registration of entry to the area

- Sensitive equipment must be locked and protected against unauthorized intrusion

Emergency planning

- Internal emergency plan for the evacuation and protection of employees

- Outer emergency plan for the protection of neighboring population

\section{Conclusion}

The risk assessment represents one of the steps of total risk management, when the results of risk assessment provide necessary information for the proposal of measures designed to reduce risks, prepare emergency plans etc. The risk assessment can also substantially contribute to the prevention of major accidents before building objects in the phase of region-planning. According to the Act on crisis management, the administrative bodies are obligated to keep the summary of risk sources and to analyze endangerment in their territories, but this assessment is not performed to larger extent due to vague competencies and missing method.

This study on non-classified risk sources contributes to the practice especially in industrial zones, other industrial plants, and state administration, providing them with possible procedure of the risk assessment of non-classified risk sources.

\section{References}

[1] Průmyslové zóny [Industrial zones, online]. Available at: http://www.prumyslove-zony.cz/blog/prumyslove-zony-53 [cit. 2013-04-12]

[2] ŠENOVSKÝ, P. Statistika zásahů HZS ČR v průmyslových zónách v letech 1997 - 2004 [Statistics of Czech Fire Rescue Services interventions in industrial zones in the years 1997 2004]. In Sborník konference Ochrana obyvatelstva 2007. Ostrava : SPBI, 2007. pp. 358-365. ISBN 978-80-86634-51-5

[3] PAVLISKA, P. Studie bezpečnosti areálu průmyslové zóny [Study of industrial zone safety]. Ostrava: VŠB - TU Ostrava. Fakulta bezpečnostního inženýrství. 2010.64 pp.

[4] ČESELSKÁ, T., ŠALÁTOVÁ, J., ŠENOVSKÝ, M.: Průmyslová zóna Ostrava Hrabová [Industrial zone Ostrava-Hrabová]. In Sborník konference Požární ochrany 2008. Ostrava : SPBI, 2008, pp. 83-93 ISBN 978-80-7385-040-1

[5] ARAMIS „Accidental Risk Assessment Methodology for Industries in the framework of the SEVESO II directive", User Guide, contract number: EVG1-CT-2001-00036, December 2004, http://mahb.jrc.it/fileadmin/ARAMIS/downloads/ ARAMIS_FINAL_USER_GUIDE.pdf

[6] DGRNE (Direction Générale des Ressources Naturelles et de l'Environnement), Walloon Region Ministry, Belgium, 2000, Vade Mecum: Spécifications techniques relatives au contenu et à la présentation des études de sécurité, Cellule Risque d'Accidents Majeurs

[7] Delvosalle C., Fiévez C., Pipart A.: ARAMIS Project, Deliverable D.1.C., 2004

[8] Metodický pokyn odboru environmentálních rizik Ministerstva životního prostředí pro postup při zpracování dokumentu „Analýza a hodnocení rizik závažné havárie“ podle zákona č. 59/2006 Sb., o prevenci závažných havárií. Věstník Ministerstva životního prostředí, částka 3, roč. 17, s. 1 - 15, ISSN 0862-9013

[9] KELNAR, Lubomír. Metodologie pro identifikaci a vyhodnocení synergických a kumulativních jevů - Část 1 Metodologie pro studium synergických a kumulativních jevů [Method for the identification and assessment of synergetic and cumulative effects - Part 1: Method for the study of synergetic and cumulative effects, online]., Praha, Ministerstvo životního prostředí, 2002, 30 pp., available at: http://www. mzp.cz/C1257458002F0DC7/cz/metodicke_pokyny_ odboru_enviro_rizik/\$FILE/oer_MP_KSJ_cast_1-2002.pdf [cit. 2013-04-17]

[10] KELNAR, Lubomír. Metodologie pro identifikaci a vyhodnocení synergických a kumulativních jevů - Část 2 Návod na použití metodologie [Method for the identification and assessment of synergetic and cumulative effects - Part 2: Guidance on the method use, online]., Praha, Ministerstvo životního prostředí, 2002, 32 pp., available at http://www. 
Acta Mechanica Slovaca

Journal published by Faculty of Mechanical Engineering - Technical University of Košice

mzp.cz/C1257458002F0DC7/cz/metodicke_pokyny_odboru_enviro_rizik/\$FILE/oer-MP_KSJ_cast_2-2002.pdf [cit. 2013-04-17] 